\title{
Juvenile Justice System in Turkey
}

\author{
S. Çoban
}

\begin{abstract}
Turkey acceded to the Convention on the Rights of Children in 1995, and in 2005, the Turkish Child Protection Law was enacted. This study reviews the progress and irregularities of the Law's implementation of Turkish juvenile justice system. Te purpose of the study is to reveal the progress and misapplications in the juvenile justice system in the light of legal regulations. A literature review on the present situation of the juvenile justice system after 2005 is employed for this purpose. The results of the review indicated that children's rights in criminal justice process are protected by the law, however as indicated in the literature review, in practice there are many problems related to the prosecution process, period of detention, the structure of juvenile courts and penal institutions. In conclusion, which measures could be taken to enhance the juvenile justice system is argued.
\end{abstract}

Index Terms-Juvenile justice, justice system, child protection law, Turkey, juvenile delinquency, reformatories.

\section{INTRODUCTION}

The main aim of this article is to discern the problematic issues in Turkey's juvenile justice system and to suggest solutions for these issues. In the first section, there is a review of the regulations made since the 1990s in the juvenile justice system. In the second section, the contradictions of the juvenile justice system in practice are analyzed. In the conclusion, measures to be taken in order to enhance the juvenile justice system in the restorative justice perspective are recommended.

\section{METHOD}

This study aims to discuss what new regulations bring in terms of human rights in the juvenile justice system in Turkey. The current situation of the system and what it brings in terms of children's rights has been has been a matter of debate. Non-governmental organizations, occupational organizations and academic institutions as well as state institutions are taking part in debate. Thus there has been a wide literature on the transformation of juvenile justice system and children's rights policy in Turkey since 2005.

This article is a literature review on this transformation process. It aims to reflect the debates on the issue from different and critical perspectives. In the first part, the structure and the working of juvenile justice system in Turkey according to law is presented. In the second part "Juvenile Justice System in Turkey", the contradictions between the law and operation of justice system in practice are reviewed. In discussion, the results of these

Manuscript received November 21, 2014; revised January 20, 2015.

Sevgi Çoban is with the Department of Sociology, Hacettep University 06800, Ankara, Turkey (e-mail: coban.sevgi@gmail.com). contradictions are argued in a human rights -specifically children's rights perspective.

\section{JUVENILE Justice System IN TURKEY}

\section{A. Child Protection Law}

The Convention on the Rights of Children was arranged by the United Nations General Assembly and came into effect on 2 September 1990. Including Turkey, 145 states agreed to this convention. Turkey became a party to this convention on 2 September 1995.

The Child Protection Law entered into force in 2005. The Law on the Establishment, Duties and Adjudication Processes of Juvenile Courts has been in effect since 1979 in Turkey. With this regulation related to juvenile courts, probation and conditional suspension has introduced legislation to protecting children from prison sentences [1]

These alternative punishment execution methods enable children to develop while in the custody of experts and family members; protect children from being labeled as criminals and prevent them from being in contact with criminals and thus becoming a professional criminal which is common while incarcerated. The literature indicates that newcomers who are sentenced to prison are likely to be culturally assimilated by other criminals in prison and learn criminal techniques, particular values, and cultures, which is called "prisonization" [2]-[4].

Children in need of protection and children involved in crime are subject to the Child Protection Law. Every person under the age of eighteen is defined as a child. Children in need of protection are defined as children whose physical, mental, ethical, social and emotional development and security are at risk or as children being neglected and abused. Children victimized by crime are considered to be in need of protection. According to the law, children involved in crime are children who are being investigated and prosecuted or subject to security measures with the suspicion of committing actions which are defined as crime by the law.

The regulations indicated below have been made in accordance with the Child Protection Law in order to maintain international standards for children in need of protection [5]:

- Special arrangements for the sensitive treatment and protection of child victims,

- An increase in the number of children's courts,

- Provision of protection for children by civil society organizations.

Article No. 19 of the Child Protection Law enables the suspension of correction for crimes that require a maximum 2-year imprisonment or criminal fines under such circumstances [6]:

- If the child has not been sentenced before, 
- If investigation gives the impression that suspension will deter the child from being involved in crime again,

- If suspension is considered to be a better choice for the child's development and effective adaptation for the society,

- If the harm caused to the victim by the child is fully compensated.

According to Article No. 21, children under age 15 cannot be arrested for crimes that require imprisonment for a maximum of five years [6].

Article No. 23 is related to deferring the announcement of the verdict. If the child was sentenced to imprisonment for less than three years or ordered to pay to a fine, announcement of the verdict can be deferred in limited circumstances.

Article No. 24 allows for mediation for crimes requiring confinement sentences, which the lower limit is a maximum of two years (if the child is under 15, the upper limit is a maximum of three years) or fines.

The law also forces prosecution offices and police stations to have children's units, courts to employ social workers to conduct investigations and prepare reports on children.

With the Child Protection Law, the probation system is considered as an alternative to imprisonment. The law specifies measures for the protection of the children's educational, psychological and health status. The law also identifies measures to be taken by children's units of the Office of the Chief Public Prosecutor, law enforcement offices and experts employed in these units for the children in need of protection and the children involved in crime.

More than 5,000 cases in which the suspect is a child were heard by Turkish courts in 2009 [7]. The sentence types were mostly juridical control, treatment and probation, alternative penalties, suspension and probation, deference of the announcement of the verdict, conditional release, home imprisonment, and effective repentance for these cases.

\section{B. Juvenile Courts}

Juvenile courts are particular courts for children in which the prosecutors and judges have had special training and social workers report the children's situation and direct the prosecution process. The law on juvenile courts came into force in 1979. The first juvenile court in Turkey was established in Ankara in 1987 [8].

The basic idea of the Law on the Establishment, Duties and Adjudication Processes of Juvenile Courts is that children are in the critical stage of the development process and adjusting to society, and that the justice system for children must not cause labeling or exclusion; on the contrary, it must foster rehabilitation and reintroducing children to the society.

Article 4 of the Child Protection Law (2005) differentiates between the juvenile justice system and the justice system in general:

- In investigation and prosecution processes, the treatment of the child must be sensitive,

- The sentence must be appropriate and must protect the child's personal development, education, personality and social status,

- Imprisonment must be considered as the last resort,

- If the child is confined, he/she must be kept in units for children, not together with adults,

- In all stages of the process, the child's identity must not be revealed to the public.

According to the law of juvenile courts, social experts are involved in the prosecution process only by writing social examination reports on children. To help provide a better understanding of children's problems social workers, psychologists, educators and such experts are to be employed in the juvenile justice system according to this law. The experts report to the court on the child's situation, including the living standards of the child as well as the reason for his/her involvement in crime and his/her problems. Yet, social reports are not taken into consideration by judges during the trials [9].

\section{Head of Department of Probation and Support Services}

In 2007, the probation system was established in Turkey. The Law on the Establishment and Duties of the Department of Probation and Support describes the probation system as "socially based practices applied in accordance with the probation plans in the time periods specified by the courts, which the suspect or the sentenced is provided with the services, programs and resources he or she needs to be reintroduced to society" [10].

The probation system offers alternatives to confinement that cause the social exclusion of the sentenced by being separated from society such as rehabilitation and probation, training, postponement of the announcement of the verdict, conditional release, effective repentance, and rehabilitation in the institutions and such.

The probation system is not only based on the reparative alternatives of confinement but also the examination of the children's life conditions and through these examinations creates solutions for the juvenile delinquency problem. Accordingly, expert personnel must be employed by the probation offices as well as by the juvenile courts. These experts prepare reports on behalf of the sentenced. Experts must have a license degree in education, psychology, and/or sociology formation [11].

Probation units are responsible for preparing reports on the life conditions of children who have been found guilty. These reports must include information about current and previous crimes, relation to the $\operatorname{victim}(\mathrm{s})$, family, education, socioeconomic status, settlement, social surroundings, health, addiction, cognitive skills, attitudes and behaviors as well as a person's identity and contact information. Additionally, experts must specify the data gathering technique (for instance, how many interviews have been conducted, which documents were examined) in this report.

According to the Department of Probation and Help statistics, in 2011, 5.000-6.000 children were put on probation each month. Nearly half of the probation rules for children is related to rehabilitation and probation.

\section{Children's Police}

The children's police was established in 2001 on the grounds of the Convention on the Rights of the Children. The children's police must have training for children's development characteristics, behavioral sciences, interview techniques and communication skills. The children's police 
personnel must also master the legal regulations; Turkish child protection system, agencies and institutions are responsible for child protection and coordination of these agencies and institutions.

In children's police offices, there are child care units where abused and neglected children, children in need of protection, runaway and truant children, child refugees, children living and working on the streets, children victimized by crime, and children whose identity cannot be determined are taken [12]. According to the by-law of the children's police department, there must be expert officers in children's police offices to detect these children's problems and socio-economic status. These reports are submits to the court in the prosecution process.

\section{Turkish JuVEnile Justice System In Practice}

One of the most important problems in the law enforcement process is that not all police stations have children's police units; thus, some of the children taken to a police station encounter officials who do not have the proper background and training for treatment to children in prosecution. A second one manifests itself in questioning the child. According to the Child Protection Law, children must be questioned in convenient settings in which there are only limited people that are officially related to the prosecution. It is stressed that most of the time children cannot be provided with convenient settings; most of the time children are questioned more than once, during the questioning, people not officially related to the case are present [13].

One of the main problems in the investigation process is related to children detained on suspicion of terrorism: The absence of children's police when children are involved in ethnic conflicts. Children taken to police stations are not questioned by public prosecutors, their families not informed and no legal representatives such as lawyers or family members present. The problem of children detained on suspicion of terrorism has drawn public reaction and concern about children's rights [13]. However, in 2010, new legal regulations that prohibit any sentences for children under eighteen for participating in illegal meetings and demonstrations and for making propaganda in support of illegal organizations entered into force. This regulation is promising for protection of the children's rights.

According to the results of research conducted by Akdam in 2006 [14] that was conducted with 2,930 children's police officers in Ankara, Istanbul, Gaziantep and Adana, officers perceive that the Child Protection Law and legal regulations for children's police to be inadequate for protecting children's rights. Thirty seven percent of the participants did not agree with the statement "the children's police department meets the requirements"; $34.8 \%$ stated undecided. Similarly, $47 \%$ did not agree with the statement "the structure of the children's police branch office meets the requirements". Forty nine per cent of the participants thought legal regulations and practice contradict each other while $26,9 \%$ were undecided. Seventy five per cent of the participants did not agree with the statement "children's police is able to take initiative in favor of not legally proceeding the petty crimes." In other words, a considerable proportion of the police officers cannot take initiative to solve crime without further legal procedures. Forty six per cent of the officers did not agree with the statement "the police is able to work together with social worker"[15]. These results indicate that the children's police department does not have sufficient authority to secure children's rights in the justice system.

In $2008,6.42 \%$ of the total number of the accused persons prosecuted in Turkish criminal courts were children 12 to 17 years old [15]. In accordance with the regulations of the Child Protection Law Article 36, 6,974 children were sentenced to probation in 2011 [16], [17].

According to a 2009 UNICEF report, $75 \%$ of children in prisons and juvenile prisons were children who were awaiting trial [13]. The average duration of a trial is 414 days for juvenile courts and 502 days for high criminal courts [18]. To make a comparison, in the US state of Washington, the duration of trial is a maximum of 60 days. This falls to 30 days if the child is under arrest. The length of trial in Turkey is a great disadvantage for children in that children are kept away from their families, education and their social life. More important, the longer the trial is, the more likely it is that the juvenile is labeled as a criminal and be excluded by the community.

A major problem in the prosecution process is that juvenile courts in Turkey are insufficient both in number and in quality. According to the law, juvenile courts must be established in every city [19]. However, the total number of juvenile courts were only 11 in 2003 and 71 (59 of them are juvenile courts and 12 of them are juvenile high criminal courts) in 2010. In addition, some of the juvenile high criminal courts was closed by 2009 , decreasing to seven [20]. There are juvenile courts only in Ankara, İstanbul, İzmir and Trabzon today [21].

Because juvenile courts were not established in every city in Turkey, some of the children are prosecuted in adult courts. According to UNICEF report, in 2007, more than half of the accused children in Turkey were prosecuted in adult courts [13].

The absence of juvenile courts in some cities and other courts not having special units for children causes serious problems. Furthermore, in juvenile courts a limited number of social workers, experts, and supervisors, as well as lack of supervision mechanisms are subject to criticism for weakening the juvenile justice system [21]. Because juvenile courts are limited, the cases accumulate and the justice system slows down. This problem is stressed in European Commission Progress Report of the Prime Ministry's Human Rights Presidency. The dearth of children's prosecutors, children's psychological examinations being skipped, and insufficient numbers of experts employed for this examination are cited as basic problems of the Turkish justice system [19].

Experts' inappropriate training for preparing reports is another point. In the law, there is no regulation for who can be employed as social worker; thus, people graduated from universities' pedagogic departments can be employed as social workers. In the Turkish Ministry of Justice strategic plan 2010-2014, it is indicated that the definition of the social worker must be clearly stated [22]. Second, social workers 
are not provided with the required materials and resources for conducting examinations of the children's lives and social environments. Social workers do not have the resources to visit the child's home, family and school. Third, the Court of Appeals does not have enough officers for supervising children's cases [23].

Even if experts have training for the examination of children, the reports based on these examinations can present very limited information on children's life conditions. In the Search Report on the Application of the Child Protection Law, it is indicated that social workers do not visit children's homes and do not make interviews with family member of children. Most of the time, these reports are based on fifteen minute interviews with children and no other examinations are made [24].

As indicated in the UNICEF report [13], reformatories for children are inadequate in number and quality. Currently,

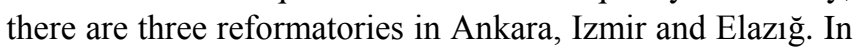
2010 , only 135 of the 2622 children in the penal institutions were in reformatories [24]. Others have been sent to the prisons. The lack of capacity causes the duality of punishment execution. Some of the children are sent to reformatories, while others are sent to children's prisons, which have harsh conditions with regards to reformatories.

The Human Rights Commission of the Grand National Assembly of Turkey established a subcommittee for investigating rights of the children in penal institutions in 2009. The results of the examinations are as such: Children are affected negatively by the long lasting appellate procedure. In the Adana-Pozantı prison, children and adults are housed together. Because of the extensive work load of the prison personnel, sometimes children's ages cannot be assessed correctly (because of the late identity registration, some of the children are recorded as being younger than they had been); thus, in the children's prisons, there may be persons older than eighteen. In addition, because there is not a camera system in the corridors and dorms are crowded, younger children sometimes are harmed by older children [24]. Furthermore, some of the prisons and reformatories are short of expert personnel. In this report, three prisons in Adana, Izmir and Kayseri were recommended by the authorities to be closed because of the poor conditions.

Children who are released from a penal institution face many problems later on. Many of them have exactly the same troubles they faced before the punishment due to poverty, unemployment, substance abuse and gang membership. There are not any institutions for monitoring children and preventing the risk of recidivism. Compounding the problem, information is limited about these children, because there are no organizations working on the rehabilitation process or monitoring children after execution of the sentence. Within this framework, first children must be encouraged to attend school or vocational education. If they have already completed their education, they should receive counseling to assist them with finding a job. Finally, the protection commissions should provide children with shelter and health care. This goal cannot be fulfilled without the cooperation between commissions and SSCPA; yet this cooperation is presently loose and frequently disrupted. One of the reasons for the failure of this cooperation is that measures to be taken indicated by law are not known well by SSCPA personnel [24].

A second point about the children's situation after release is that protection commissions are responsible for ensuring that children continue their education. According to a by-law of the Turkish Ministry of National Education, children who do not attend school for two semesters are dismissed from school. Children in penal institutions can be exempt from this rule with the legal excuse of their detention period. Nevertheless, this regulation is neglected most of the time according to Human Rights Commission of the Grand National Assembly of Turkey. Moreover, there is no preparatory program for them to attend school later on [24].

One of the major problems of the protection commissions is the absence of a standard database about children undergoing the criminal justice process. Existing statistics were found insufficient to help devise a policy for these children [23].

\section{DISCUSSION}

In summary, the reparative perspective on juvenile justice has a sound legal basis in Turkey since the 2000s. However, this basis has been weakened by many failures in practice. Thus reparative and rehabilitative approaches are still not as effective as they can be. The most important reason for this ineffectiveness is that the reparative principle is not valid (taken into account) until the jurisdiction. In the investigation and prosecution processes, children can be treated badly by the police and can be confined in inappropriate conditions such as prisons. Some of the children are treated well by the children's police. However, many others are caught by other police officers and in this process, can be insulted and beaten. Also, children kept under detention with crime suspects are kept in prisons for very long periods from several months to two years. This has negative outcomes for children: When compared to reformatories, prisons have many disadvantages for children. For example, while children in reformatories can work outside and visit family every year, working outside and on leave for family visits are prohibited in prisons. Furthermore, children sometimes stay together with the adult criminals in closed prisons. First, adults can harm children; second, juveniles in prison are at risk of being put through the "prisonization" process, which inhibits reintegration into society later in a long term.

In conclusion, while the juvenile justice system is reparative in principle, for children kept in detention with crime suspects, there is an unintended retributive principle in effect. To correct this, measures to be taken are as such: The pedagogical approach must be actualized. For this purpose, social workers and experts working in children's police units and juvenile courts must be provided by both resources to conduct investigations of children's social environments (socio-economical status, family life, school success, etc.). In addition, jobs of social workers and experts must be clarified in the law for them to have authority to intervene in the prosecution with the reports they prepared. Third, children's police must be more actively involved in protecting children under investigation and in detention.

In the Joint Platform for the Human Rights report [9], as a 
solution of the problems mentioned above, it is recommended that children's crimes be considered from the children's perspective instead of a adult-centered justice model. From this perspective, crimes that children commit can be evaluated through the "antisocialiata" (behaviors harmful for the society and social life) principle instead of the legal definitions of crimes. A model in which juvenile suspects do not become the object of law enforcement officers and are excused from criminal justice procedures but are subject to rehabilitative practices is recommended. Such a model is essential for strengthening the reparative character of the juvenile justice system in Turkey.

The lack of a monitoring mechanism for children released from penal institutions is also a problem especially for specialists working on the reformation of the juvenile justice system. This mechanism would be more functional if it is developed by NGOs to help children adapt to outside world. This mechanism must be independent to prevent children from being labeled as criminals and being excluded from society.

In Turkey, there are no NGOs actively monitoring children's rights in the juvenile justice system. However, NGOs' monitoring based on prison visits, interviews with the children, criminal justice personnel is crucial especially for the enhancement of detailed children's quality of life.

Another important point is that the aim of the juvenile justice system should not only be reintegrating former convicted children but also determining the risk factors for juvenile delinquency and developing a protective policy on delinquency. In this respect, a national database including data on socioeconomic characteristics, social problems, victimization and deviance experiences of the children in Turkey must be created. This would be the first step for understanding and intervening children's social problems that lead children into committing crime.

\section{REFERENCES}

[1] S. Uluğtekin, "Juvenile courts and social examination reports," Çocuk Mahkemeleri Ve Sosyal Inceleme Raporlart, Ankara: Union of Bars of Turkey Publication, 2004.

[2] D. Clemmer, The Prison Community, New York: Holt, Rinehart and Winston, 1940 .

[3] M. T. Zingraff, "Prisonisation as an inhibitor of effective resocialization," Criminology, vol. 13, no. 3, pp. 366-388. 1975.

[4] A. Kuanliang, J. R. Sorensen, and M. D. Cunningham, "Juvenile inmates in an adult prison system: Rates of disciplinary misconduct and violence," Criminal Justice and Behaviour, vol. 35, no. 9, pp. 1186-1201, 2008.

[5] UNICEF. (2010). Unite for Children: Country Profile of Turkey. [Online]. Available: http://www.unicef.org/turkey/ut/ut2_2010.html

[6] B. S. Akpunar. The Child Protection Law (Çocuk koruma yasası). [Online].

Available:
[7] Department of Probation and Help. (2011). [Online]. Available: http://www.cte-dsm.adalet.gov.tr

[8] A. Doğan. (2004). Juvenile Courts (Çocuk Mahkemeleri). [Online]. Available:

http://www.sosyalhizmetuzmani.org/cocukmahkemelerishuz.doc

[9] A. Atilgan and E. U. Atilgan. (2009). The Evaluation of the Regulations and Application on Children'S Rights Paradigm and Prevailing Principles of Juvenile Justice in Turkey. [Online]. Available: http://www.courts.wa.gov/court_rules/?fa=court_rules.rulesPDF\&rule ID=supJuCR07.08\&pdf $=1$

[10] İ. Usta and H. Öztürk, "Probation system," Penal Law Journal, vol. 5, no. 13 , pp. $2-44.2010$.

[11] M. C. Özkaya. (2010). A Humanistic Approach on Punishment Execution: Probation System. [Online]. Available: http://www.sosyalhizmetuzmani.org/denetimliserbestlik.htm

[12] M. Güler. (2010). Children's Police. [Online]. Available: http://www.sosyalhizmetuzmani.org/cocukpolisi.htm

[13] UNICEF. (2009). Justice for Children. [Online]. Available: http://www.unicef.org.tr/en/content/detail/71/justice-for-children.html

[14] M. Akdam, "An evaluation on the activities of children's police (Emniyet Genel Müdürlüğü'nün Çocuk Polisi Uygulamaları Üzerine Genel Bir Değerlendirme)," Unpublished MA Thesis, Ankara University, Ankara, pp. 60-61, 2006.

[15] TURKSTAT. (2008). Sentenced Juveniles. [Online]. Available: http://www.turkstat.gov.tr/VeriBilgi.do?tb_id=1\&ust_id=12

[16] T. İçli, Child, Crime and Street, General Directorate of Family and Social Research Publications, Ankara, 2009.

[17] Department of Probation and Help Probation Statistics. (2011). [Online]. Available: http://www.adalet.gov.tr/stratejikplan/AdaletBakanlığ1StratejikPlan12 010-2014.pdf

[18] A. Doğan. (2004). Juvenile Courts. [Online]. Available: http://www.sosyalhizmetuzmani.org/cocukmahkemelerishuz.doc

[19] Prime Ministry Human Rights Precidency European Commision Progress Report. (2009). [Online]. Available: http://www.ihb.gov.tr/dosyagoster.ashx?id=8

[20] S. Uluğtekin and Y. B. Acar, "Juvenile courts and probation officers as change agents in Turkey," International Journal of Humanities and Social Sciences, vol. 1, no. 3, pp. 199-203, 2011.

[21] Prime Ministry Human Rights Precidency. [Online]. Available: http://www.ihb.gov.tr/dosyagoster.ashx?id=8

[22] Republic of Turkey. [Online]. Available: http://www.adalet.gov.tr/stratejikplan/AdaletBakanlığıStratejikPlan12 010-2014.pdf

[23] İstanbul Bar. (2007). [Online]. Available: http://www.istanbulbarosu.org.tr/Yayinlar/BaroKitaplari/ckkuiakr.pdf

[24] Grand National Assembly of Turkey Human Rights Commission. (2010). [Online]. Available: http://www.turkhukuksitesi.com/showthread.php?t=48102

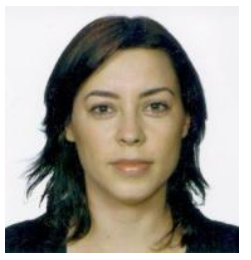

Sevgi Çoban was born on April 28, 1981. She had her bachelor, MA, and $\mathrm{PhD}$ degrees at Hacettepe University. She graduated from Hacettepe University in Ankara, Turkey in 2003. She got her master degree in 2006 from Department of Sociology, Hacettepe University. In 2012, she finished her PhD at the same department.

She is a research assistant at Hacettepe University since 2006 in Ankara, Turkey. She has been at Rutgers University, Newark, $\mathrm{NJ}$ as a visiting scholar for six months between 2010 and 2011. Her field of study includes sociology of crime, juvenile delinquency and sociology of work. 